\title{
Reputational Threats Online: Social Media as a Simultaneous Agent of Crisis and Tool for Response and Resolution in the Case Study of an American Academic Library
}

\author{
Margaret C. Stewart \\ University of North Florida \\ 1 UNF Drive, Jacksonville FL 32224 United States \\ Maria Atilano \\ University of North Florida \\ 1 UNF Drive, Jacksonville FL 32224 United States
}

\begin{abstract}
This paper details a reputational threat to an American academic library where a viral social media post and associated negative comments misrepresented the institution and brand's values. Immediately, the marketing librarian responsible for social media responded to the threat by engaging directly with the library consumers, sharing content and information with the broader online community, and reinforcing the library's values and commitment to consumers. While the resolution to the crisis was mostly favourable, the event was unanticipated and invited a keen learning opportunity that is documented in this case study. Reflections and takeaways from this incident are discussed in the context of emerging literature on crisis communication, reputation threats, and social media.
\end{abstract}

Keywords — social media, academic library, reputational threats, online crises, crisis communication

SUGGESTED CITATION: Stewart, M. C., \& Atilano, M. (2018). Reputational threats online: Social media as a simultaneous agent of crisis and tool for response and resolution in the case study of an American academic library. Proceedings of the International Crisis and Risk Communication Conference (pp. 24-26). Orlando, FL. USA. Nicholson School of Communication. https://doi.org/10.30658/icrcc.2018.7

\section{INTRODUCTION}

Social media are unique tools that they can serve as both an agent of a crisis, and as a means for crisis communication and, potentially, resolution. Social media are online platforms that people use to communicate and interact with one another, organizations, brands, agencies, and other entities who maintain a social presence. Popular social media tools include Facebook, Twitter, Instragram, SnapChat, and a host of other digital platforms that provide outlets for engagement, collaboration, and information and content sharing, social presence can place individuals, brands, and businesses in a vulnerable position when it comes to reputation management. A clear example of this occurred during Hurricane Harvey; Joel Osteen's Lakewood Church in Houston was criticized on social media regarding their response to the community during the storm. The reputations of both Osteen and the Church were in compromising situations as social media conversations ignited reputational threats [1]. Here, a case study of an American academic library is presented which demonstrates the paradoxical nature of social media in reputational crises, and provides a summary of lessons learned and recommendations for effective crisis response.

\section{CASE STUDY}

The University of North Florida's Thomas G. Carpenter Library is located in Jacksonville, Florida, and serves university library, faculty, staff, and members of the local community. On April 17, 2017, a student intern posted a photograph to the 
University of North Florida's Student Union Facebook page with the following comments: "Finals are frustrating, but remember... \#MakeYouSmileMonday \#LoveUNF \#SWOOPLife.” While this photograph was not taken in the Carpenter Library, it depicted an academic library in a negative light. With stacks of books in the background, a large-scale poster states: "Cries carry in the library. For the courtesy of those studying around you, please relocate to the hallway if you wish to sob audibly. Thank you.” The poster also shows two crying, cartoon emojis. The Student Union post tagged the Carpenter Library’s Facebook account (@unflibrary).

Twenty-four hours after the photograph was posted, it went viral. The post was shared 181 times, and received 189 reactions including Like, Haha, Wow, Sad, and Angry. Comments from Facebook users, who included current UNF students and members of the Jacksonville community, included questions about where the inflammatory poster was located in the Carpenter Library. Many students were offended by the insensitive message imparted by the photograph, and assumed that the Carpenter Library was making light of the stress involved with finals week exams and studying.

Shortly after the post went viral, the President of the University received an "official call of action" from a noncampus organization representative who advocates for students with mental health and emotional health issues. The President forwarded this message to the Dean of the Library and other University Administration representatives.

This inadvertent social media crisis resulted in a loss of goodwill and brand credibility between the Library and its customers. The timing was especially vexing for Library staff due to the amount of hours, money and effort spent on library services and resources at the end of the semester. At the same time that customers were complaining that the Library was insensitive to student needs, Library staff were busy planning numerous events and activities to help relieve student stress and anxiety during final exams.

\section{RISK MANAGEMENT RESPONSE}

Once it was clear that the Carpenter Library was at risk for fallout, the Librarian who monitors social media engagement and activity took immediate action. The Librarian contacted a Student Union marketing staff member, asking for support in controlling the situation. The Student Union representative confirmed that an unsupervised student intern posted the photograph. Students who commented negatively or shared the Student Union's post were immediately contacted from the Library's official Facebook account with assurance that the photograph was not taken in the Carpenter Library, and that the Carpenter Library did not currently have the incriminating poster on display. While most users who shared the Student Union's post had their accounts set to private, some users allowed non-friends to comment on their posts. The Librarian commented with a disclaimer to more than a dozen shared posts and comments.

The risk management response also included a message sent to Library Administration. In an assuring email sent to the Library Dean and Directors, it was made clear that the Library had responded "to the negative comments... the poster is NOT on display in the library, and we do not condone its message.”

In the end, the Student Union Facebook post was deleted 25 hours after it was first posted.

\section{RESOLUTION}

The true impact of the Facebook library photograph crisis cannot be quantified. While more than a dozen customers were contacted following their negative comment or share, many others were unreachable due to their privacy settings. While this is unfortunate, it is important to keep small successes in mind when responding to a social media crisis. One student who shared the UNF Student Union photo posted the following comment to her account: “SO I CAN'T EVEN CRY IN MY OWN LIBRARY? \#smh I thought my friend Tommy G [nickname for the Carpenter Library] would be a little more empathetic \#finals \#finalsweek.” This comment shows the student's frustration with the Carpenter Library's apparent lack of concern for student mental health; to her, it is almost a betrayal.

As part of their damage control process, Library staff responded to this student on her Facebook page. "Hello! Just so you know, this photo was not taken in the Thomas G. Carpenter Library. Although we do agree that it's rather humorous, we would rather support our students with finals week puppies and coffee.” The student responded with relief, expressing her admiration for the library and its resources. "Yaaaaayyyyy! That's the Tommy G I know and love. Tommy G is one of my favourite places in the WHOLE WORLD (and my official crying spot/refuge during stressful times).”

Because of this brush with reputational threat, the Carpenter Library has drafted crisis management and communication into their social media guidelines effective for 2018/2019.

\section{DISCUSSION}

In this particular case, the lessons learned include: (1) Accentuate the Positive, (2) Eliminate the Negative, (3) Plan for future social media crises, and (4) Revel in the small successes. These takeaways from the case, and the valuable insight gleaned through the process of managing this reputation crisis on social media echo some of the established best practices of crisis communication [2][3][4]. Another key to addressing this particular case was the process of Social Listening.

Social Listening invites prompt response to reputation crises online and is defined as "an active process of attending 
to, observing, interpreting, and responding to a variety of stimuli through mediated, electronic, and social channels” [5]. Engaging in Social Listening as an active process routinely throughout everyday social media strategy enable a social media manager and/or crisis communication professional the opportunity to immediately identify, field, address, and respond to reputational threats from a very early stage in the crisis, which may influence the length and outcome of the crisis event.

Social Listening is the opening stage of the STREMII model for social media crisis communication [6] and is identified as an ongoing item throughout the STREMII model's stages in the proposed revision of the model [7]. STREMII is developed according to the theoretical framework to Coombs' [8][9] Situational Crisis Communication Theory (SCCT) and is explored in the context of hurricanes. While, its application is not limited solely to natural disasters, the model can benefit from additional application and analysis, and requires frequent adaptation as the landscape of social media continuously changes.

The lessons learned from the present case study of the UNF Library's reputational threat and associated crisis communication on social media highlight some published recommendations for crisis management online. A summary of these guidelines include: (1) Practice Social Listening routinely, (2) Prepare for potential crises, (3) Identify clear target audiences, (4) Maintain a social presence on relevant platforms, and (5) Readily prepare and adapt messages according to crisis and audience needs, (6) Be responsive and engage with your consumers online [6][10].

\section{CONCLUSION}

In closing, this case study presents an incident of reputational threat caused by a social media post to an American academic library. This account captures the experience of crisis communication on social media in an attempt to manage the reputational threat. Ultimately, the poor experience perceived by library consumers was negated and several original complainants reacted positively to the responsive efforts of the library's crisis and social media manager. This experience influenced the drafting of specific guidelines for crisis communication on social media, and this formally documented procedure is influenced by the published best practices for crisis management and social media crisis communication and will be revisited routinely as social media evolves.

\section{Author Biography}

Margaret C. Stewart (m.c.stewart@unf.edu, Ph.D., Indiana University of Pennsylvania, 2013) is an Assistant Professor of Communication Studies at University of North Florida in Jacksonville, Florida.

Maria Atilano (m.atilano@unf.edu, MLIS, Florida State University, 2012) is the Marketing and Student Outreach Librarian at the University of North Florida's Thomas G. Carpenter Library in Jacksonville, Florida.

\section{REFERENCES}

[1] Shapiro, E. \& Fowler, T. (2017). Joel Osteen's Houston church receives evacuees after backlash on social media. Retrieved from http://abcnews.go.com/US/joel-osteens-church-receiving-houston-residents-shelter-backlash/story?id=49489447

[2] Seeger, M. W., Sellnow, T. L., and Ulmer, R. R. (2003). Communication and organizational crisis. Westport, CT: Praeger.

[3] Seeger, M. W. (2006). Best practices in crisis communication: An expert panel process. Journal of Applied Communication Research, 34(3), 232-244. https://doi.org/10.1080/00909880600769944

[4] Sellnow, T. M., \& Seeger, M. W. (2013). Theorizing crisis communication. Malden, MA: John Wiley \& Sons, Inc.

[5] Stewart, M.C. \& Arnold, C. L. (2017). Defining social listening: Recognizing an emerging dimension of listening. International Journal of Listening, 32(2), 85-100. https://doi.org/10.1080/10904018.2017.1330656

[6] Stewart, M. C., \& Gail Wilson, B. (2015). The dynamic role of social media during Hurricane \#Sandy: An introduction of the STREMII model to weather the storm of the crisis lifecycle. Computers in Human Behavior, 54, 639-646. https://doi.org/10.1016/j.chb.2015.07.009

[7] Stewart, M. C. and Young, C. (March, 2017). Revisiting STREMII: An application of social media crisis communication during Hurricane Matthew; Paper Presentation. International Crisis \& Risk Communication Conference; Orlando, FL.

[8] Coombs, W. T. (2007). Protecting organization reputations during a crisis: The development and application of situational crisis communication theory. Corporate Reputation Review, 10(3), 163-176. https://doi.org/10.1057/palgrave.crr.1550049

[9] Coombs, W. T. (2014). Ongoing crisis communication: Planning, managing, and responding, (4th ed.). Thousand Oaks, CA: Sage Publications, Inc.

[10] International Committee of the Red Cross (2017). How to use social media to better engage people affected by crises. Retrieved from https://www.icrc.org/en/document/social-media-to-engage-with-affected-people 